\title{
Palynomorphological Studies on some Asperula and Galium (Rubiaceae) Taxa
}

\author{
Birol BAŞER ${ }^{1 *}$, Serap AKDENIZ ${ }^{2}$, Murat KURŞAT ${ }^{1}$ \\ ${ }^{1}$ University of Bitlis Eren, Faculty of Science and Art, Deparment of Biology, Bitlis \\ ${ }^{2}$ University of Bitlis Eren, Graduate School of Natural and Applied Sciences, Department of Biology, Bitlis \\ (ORCID: 0000-0002-9305-8759) (ORCID: 0000-0002-3300-4345) (ORCID: 0000-0002-0861-4213)
}

\begin{abstract}
In this research, the genera Asperula L., Galium L.; Asperula xylorrhiza Nábelek (siirt belumotu), Asperula orientalis Boiss. \& amp; Hohen. (gökçe belumotu), Asperula arvensis L. (tarla belumotu), Galium humifusum M. Bieb. (çimen iplikçiği), Galium consanguineum Boiss. (altın iplikçik), Galium incanum L. subsp. elatius (Boiss.) Ehrend. (gür iplikçik), Galium consanguineum Boiss. (altın iplikçik), Galium mite Boiss. \& amp; Hohen. (süpürge iplikçiği), Galium spurium L. subsp. spurium (arsız iplikçik) of the family Rubiaceae, have been studied in terms of palynological properties. Examples of these taxa were collected in the field studies. 9 taxa light microscopy (IM) and scanning electron microscopy (SEM) belonging to this family were studied. As a result of this study some common traits of the taxa found out such as zonocolpate, perforate and scabrate.
\end{abstract}

Keywords: Asperula, Galium, Rubiaceae, Pollen morphology, SEM.

\section{Asperula ve Galium'un (Rubiaceae) Bazı Taksonlarının Palinomorfolojik Çalışmaları}

\begin{abstract}
$\ddot{\mathbf{O} z}$
Bu araştırmada Rubiaceae familyasından Asperula L., Galium L. cinslerine ait; Asperula xylorrhiza Nábelek (siirt belumotu), Asperula orientalis Boiss. \& Hohen. (gökçe belumotu), Asperula arvensis L. (tarla belumotu), Galium humifusum M.Bieb. (çimen iplikçiği), Galium consanguineum Boiss. (altın iplikçik), Galium incanum L. subsp. elatius (Boiss.) Ehrend.(gür iplikçik), Galium consanguineum Boiss. (altın iplikçik), Galium mite Boiss. \& Hohen. (süpürge iplikçiği), Galium spurium L. subsp. spurium (arsız iplikçik) taksonları palinolojik özellikleri açısından incelenmiştir. Bu taksonlara ait örnekler yapılan arazi çalışmalarında toplanmıştır. Bu familyaya ait 9 takson 1 şık mikroskobu (LM) ve taramalı elektron mikroskobu (SEM) kullanılarak incelenmiştir. Bu çalışma sonucunda zonokolpat, perforat ve skabrat, olması gibi bazı ortak özellikler bulunmuştur.
\end{abstract}

Anahtar kelimeler: Asperula, Galium, Rubiaceae, Polen morfolojisi, SEM.

\section{Introduction}

Rubiaceae family is a tropical cosmopolitan family represented by about 615 genera and 13200 species in the world [1]. In Turkey, it is represented by 10 genera and approximately 170 species [2]. The genus Galium, belonging to Rubiaceae family is represented by 116 taxa included in 10 sections in Flora of Turkey [3-5]. Together with new species (G. babadaghense Y1ld., G. cankirense Y1ld., G. nigdeense Y1ld., G. tuncelianum Y1ld., G. shinasii Y1ld.) added in recent years and one subspecies (G. canum subsp. ulukislaense Y1ld.), the taxa of Galium genus in Turkey have increased to 122 and 61 of them are endemic. The number of Asperula taxa spread throughout the world is 358. The total number of Asperula taxa together with the subspecies and varieties in Turkey is 57 and $30 \%$ of them are endemic [6]. There are many studies on pollen morphological characteristics of Rubiaceae family and the family has been described as eurypalinous [7-16]. Dessein et al., [15] have suggested that the palynological data of Rubiaceae family may reveal the evolutionary relations between different taxa and they may be used to

*Sorumlu yazar: baser2007@gmail.com

Geliş Tarihi: 28.11.2019, Kabul Tarihi: 14.02.2020 
support or reject taxonomic data. Erdtman [8] determined the pollen characteristics of 230 species of 120 genera. Huysmans et al., [13] studied on 6 Rubiaceae genera (Asperula, Crucianella, Cruciata, Galium, Rubia and Sherardia) spreading throughout Northwestern Europe. In the study including a total of 29 species, pollen morphology was examined using light microscope and electron microscope. Perveen and Qaiser [17] defined the pollen morphology of 50 species of Rubiaceae family in Pakistan. On the other hand, Verellen et al., [16] revealed the pollen characteristics of the taxa of the tribes Naucleeae and Hymenodictyeae [18]. In Egypt, the pollen morphological examination of eleven species and one subspecies of Galium L. genus was performed using light microscope (LM) and electron microscope (SEM). The pollen morphology of 9 taxa of Asperula and Galium genera in Rubiaceae family, using the plant samples, collected in the field studies in Elazı $\breve{g}$ and Bitlis provinces, was examined using light microscope and SEM in detail.

The present study aimed to describe the pollen morphology of 9 taxa belonging to Galium and Asperula genus belonging to Rubiaceae.

\section{Materials and Methods}

In this study, the plant samples used are taxa belonging to Asperula and Galium genera collected from Elazı $\breve{g}$ and Bitlis provinces.

Specimens investigated:

Asperula xylorrhiza Nábelek: B8-Bitlis, eastern slopes of Mount Kambos, 03.07.2013, 38 19' 29.58" $\mathrm{K}, 42^{\circ} 00^{\prime} 33.33^{\prime \prime} \mathrm{D}, 1400-1600 \mathrm{~m}, \mathrm{M}$. Karatas 1051. Asperula orientalis Boiss. \& Hohen. B8-Bitlis, eastern slopes of Mount Kambos 23.04.2014, 38 $19^{\prime} 29.58^{\prime \prime} \mathrm{K}, 42^{\circ} 00^{\prime} 33.33^{\prime \prime} \mathrm{D}, 1400-1600 \mathrm{~m}$, M. KARATAS 1633. Asperula arvensis L. B8-Bitlis, Ağaçköprü village, 02.05.2014, 38²0' $11.95^{\prime \prime} \mathrm{K}, 42^{\circ}$ 00 10,88" D, 1350-1450m, M. Karatas 1694. Galium humifusum M. Bieb. B8-Bitlis, Kambos Eastern

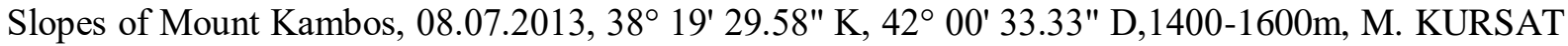
1147.Galium consanguineum Boiss. B8-Bitlis, northern slopes of Mount Kambos, 01.07.2014, 38 ${ }^{\circ} 19^{\prime}$ 23.26" K, 41 59' 42.29" D,1800-1950m, M. Kursat 2197.Galium mite Boiss. \& Hohen. B8-Bitlis, eastern slopes of Mount Kambos, 08.07.2013, 38 19' 29.58" K, 42 00' 33.33" D,1400-1600m, M. Kursat 1123.Galium spurium L. subsp. spurium. B8-Bitlis, South of Mount Kambos, 25.05.2014, 38 ${ }^{\circ}$ $17^{\prime} 52.83$ " K, 41 $51^{\prime} 15.31$ " D, 1240-1650 m, M. Kursat 1857.Galium incanum L. subsp. elatius (Boiss.) Ehrend. B7. Elazığ, Baskil, Kayabeyli Village, north of Belhan hamlet, slopes 1750-1900m. 04/07/2002 M. Kursat 3208. Galium galiopsis (Hand. - Mazz.) Ehrend. (Endemic) B7. Elazı̆̆. Kamışlık Mountain, Tarlatepe Village area, slopes 1450-1760m. M. Kursat 04/07/2002.

For light microscopy, the pollen grains were prepared for light (LM) by the standard methods described by Wodehouse [19] The following parameters, as which pollen size (Polar axis (P) and Equatorial axis (E), P/E ratio, exine, colpi long axis, colpi short axis, apocolpium and Amb diameter, exine thickness, and intine thickness were measured. Average of about 35 pollens were taken to determine the size of pollen. Photomicrographs were made with a Olympus BX-31 binocular light microscope. For scanning electron microscopy investigations, the pollens were put on stubs, stuttercoated with gold plate. The SEM examination was carried out a ZEISS supra 55 electron microscope. Pollen terminology was adopted from Hesse et al. [20] and Punt et al. [21, 22].

\section{Results}

\subsection{Asperula L.}

Asperula orientalis Boiss. \& Hohen.; Monad, isopolar symmetry, prolate-spheroidal shape. 6zonocolpate (3\%), 7-zonocolpate (59\%) and 8- zonocolpate (38\%). Morphological characteristics of pollen depending on SEM examine; Exine structure; tectate, ornamentation; scabrate-perforate. The average number of scabrae at $1 \mu \mathrm{m}^{2}: 19.25$, the average number of perforae at $1 \mu \mathrm{m}^{2}: 2.41$, the width of the scabrae: $0.14 \mu \mathrm{m}$, the length of the scabrae: $0.14 \mu \mathrm{m}$. The colpus membrane are scabrate (fig. $1-\mathrm{a}, \mathrm{b}$. fig.2-a, fig. 3-a, b)

Asperula arvensis L.; Monad, isopolar symmetry, oblate-spheroidal shape. 6-zonocolpate (35\%), 7zonocolpate $(45 \%)$ and 8- zonocolpate (20\%). Morphological characteristics of pollen depending on 
SEM examine; Exine structure; tectate, ornamentation; scabrate-perforate. The average number of scabrae at $1 \mu \mathrm{m}^{2}: 10.31$, the average number of perforae at $1 \mu \mathrm{m}^{2}: 1.71$, the width of the scabrae: 0.21 $\mu \mathrm{m}$, the length of the scabrae: $0.13 \mu \mathrm{m}$. The colpus membrane are scabrate (fig.1-c, d, fig. 2-b, fig. 3-c, d).

Asperula xylorrhiza Nábelek; Monad, isopolar symmetry, prolate-spheroidal shape. 5-zonocolpate (5.1\%), 6-zonocolpate (87.2\%) and 7- zonocolpate (7.7\%). Morphological characteristics of pollen depending on SEM examine; Exine structure; tectate, ornamentation; scabrate-perforate. The average number of scabrae at $1 \mu \mathrm{m}^{2}: 19.30$, the average number of perforae at $1 \mu \mathrm{m}^{2}: 3.77$, the width of the scabrae: $0.14 \mu \mathrm{m}$, the length of the scabrae: $0.11 \mu \mathrm{m}$. The colpus membrane are scabrate (fig. 1 -e, $\mathrm{f}$, fig.2-c, fig. 3-e, f).

\subsection{Galium L.}

Galium consanguineum Boiss.; Monad, isopolar symmetry, prolate-spheroidal shape. 6-zonocolpate $(42 \%)$ and 7-zonocolpate (58\%), (Table 1). Morphological characteristics of pollen depending on SEM examine; Exine structure; tectate, ornamentation; scabrate-perforate. The average number of scabrae at $1 \mu \mathrm{m}^{2}: 10.1$, the average number of perforae at $1 \mu \mathrm{m}^{2}: 2.22$, the width of the scabrae: $0.09 \mu \mathrm{m}$, the length of the scabrae: $0.13 \mu \mathrm{m}$. The colpus membrane are scabrate (fig.1-g, h, fig.2-d, fig. 3-g, h).

Galium mite Boiss. \& Hohen.; Monad, isopolar symmetry, oblate-spheroidal shape. 6-zonocolpate (52\%) and 7-zonocolpate (48\%). Morphological characteristics of pollen depending on SEM examine; Exine structure; tectate, ornamentation; scabrate-perforate. The average number of scabrae at $1 \mu \mathrm{m}^{2}$ : 9.61, the average number of perforae at $1 \mu \mathrm{m}^{2}: 3.27$, the width of the scabrae: $0.17 \mu \mathrm{m}$, the length of the scabrae: $0.19 \mu \mathrm{m}$. The colpus membrane are scabrate (fig. 1-1, j, fig.2-e, fig. 3-1, j).

Galium galiopsis (Hand. - Mazz.) Ehrend.; Monad, isopolar symmetry, oblate-spheroidal shape. 6zonocolpate (1.5\%), 7-zonocolpate (46\%) and 8 -zonocolpate (48\%) and 9-zonocolpate (4.5\%). Morphological characteristics of pollen depending on SEM examine; Exine structure; tectate, ornamentation; scabrate-perforate. The average number of scabrae at $1 \mu \mathrm{m}^{2}: 10.1$, the average number of perforae at $1 \mu \mathrm{m}^{2}: 2.00$, the width of the scabrae: $0.14 \mu \mathrm{m}$, the length of the scabrae: $0.17 \mu \mathrm{m}$. The colpus membrane are scabrate (fig.1-k, n, fig.2-f, fig. 3-k, l).

Galium humifusum M. Bieb.; Monad, isopolar symmetry, oblate-spheroidal shape. 6-zonocolpate (28\%), 7-zonocolpate (72\%). Morphological characteristics of pollen depending on SEM examine; Exine structure; tectate, ornamentation; scabrate-perforate. The average number of scabrae at $1 \mu \mathrm{m}^{2}$ : 14.25 , the average number of perforae at $1 \mu \mathrm{m}^{2}: 2.30$, the width of the scabrae: $0.15 \mu \mathrm{m}$, the length of the scabrae: $0.12 \mu \mathrm{m}$. The colpus membrane are scabrate (fig.1-n, o, fig.2-g, fig. 3-m, n).

Galium incanum L. subsp. elatius (Boiss.) Ehrend.; Monad, isopolar symmetry, oblate-spheroidal shape. 6-zonocolpate (88\%), 7-zonocolpate (8\%) and 8-zonocolpate (4\%). Morphological characteristics of pollen depending on SEM examine; Exine structure; tectate, ornamentation; scabrateperforate. The average number of scabrae at $1 \mu \mathrm{m}^{2}: 10.66$, the average number of perforae at $1 \mu \mathrm{m}^{2}$ : 1.62 , the width of the scabrae: $0.17 \mu \mathrm{m}$, the length of the scabrae: $0.15 \mu \mathrm{m}$. The colpus membrane are scabrate (fig.1-p, r, fig.2-h, fig. 3-o, p).

Galium spurium L. subsp. spurium; Monad, isopolar symmetry, oblate-spheroidal shape. 6zonocolpate (6\%), 7-zonocolpate (64\%) and 8 -zonocolpate (30\%). Morphological characteristics of pollen depending on SEM examine; Exine structure; tectate, ornamentation; scabrate-perforate. The average number of scabrae at $1 \mu \mathrm{m}^{2}: 12.33$, the average number of perforae at $1 \mu \mathrm{m}^{2}: 6.38$, the width of the scabrae: $0.10 \mu \mathrm{m}$, the length of the scabrae: $0.10 \mu \mathrm{m}$. The colpus membrane are scabrate (fig. $1-\mathrm{s}, \mathrm{t}$, fig.2-j, fig. 3-r, s). 
Table 1. Pollen morphological parameters of Asperula and Galium taxa

\begin{tabular}{|c|c|c|c|c|c|c|c|c|}
\hline Taxon & $\mathbf{P}(\mu \mathrm{m})$ & $\mathrm{E}(\boldsymbol{\mu m})$ & $\begin{array}{l}\mathrm{P} / \mathrm{E} \\
\text { ratio }\end{array}$ & $\operatorname{Ex}(\mu \mathrm{m})$ & In $(\mu \mathrm{m})$ & $\operatorname{clg}(\mu \mathrm{m})$ & clt $(\mu \mathrm{m})$ & Or \\
\hline $\begin{array}{l}\text { Asperula } \\
\text { orientalis }\end{array}$ & $20.53 \pm 2.67$ & $20.02 \pm 2.86$ & P-s & $1.61 \pm 0.47$ & $0.72 \pm 0.22$ & $15.40 \pm 2.19$ & $1.09 \pm 0.11$ & Sc-per \\
\hline A. arvensis & $18.70 \pm 1.52$ & $18.80 \pm 2.16$ & $\mathrm{O}-\mathrm{s}$ & $1.82 \pm 0.43$ & $0.86 \pm 0.22$ & $13.20 \pm 1.38$ & $1.38 \pm 0.49$ & Sc-per \\
\hline A. xylorrihza & $17.03 \pm 1.18$ & $18.41 \pm 2.27$ & $\mathrm{O}-\mathrm{s}$ & $1.58 \pm 0.44$ & $0.73 \pm 0.25$ & $12.41 \pm 1.37$ & $0.95 \pm 0.17$ & Sc-per \\
\hline $\begin{array}{l}\text { Galium } \\
\text { consanguineum }\end{array}$ & $17.80 \pm 1.72$ & $17.88 \pm 2.13$ & $\mathrm{O}-\mathrm{s}$ & $1.39 \pm 0.44$ & $0.67 \pm 0.22$ & $13.72 \pm 1.63$ & $1.19 \pm 0.38$ & Sc-per \\
\hline G. mite & $17.10 \pm 0.86$ & $18.94 \pm 1.65$ & $\mathrm{O}-\mathrm{s}$ & $1.73 \pm 0.42$ & $0.85 \pm 0.21$ & $12.21 \pm 1.07$ & $1.41 \pm 0.49$ & Sc-per \\
\hline G. galiopsis & $14.21 \pm 1.14$ & $15.33 \pm 2.91$ & $\mathrm{O}-\mathrm{s}$ & $1.84 \pm 0.36$ & $0.93 \pm 0.18$ & $9.11 \pm 1.20$ & $0.97 \pm 0.23$ & Sc-per \\
\hline G. humufisum & $14.35 \pm 2.08$ & $12.07 \pm 2.63$ & S & $1.50 \pm 0.47$ & $0.59 \pm 0.17$ & $9.89 \pm 2.05$ & $0.87 \pm 0.22$ & Sc-per \\
\hline $\begin{array}{l}\text { G. incanum subsp. } \\
\text { elatius }\end{array}$ & $18.68 \pm 1.93$ & $16.86 \pm 2.36$ & P-s & $1.73 \pm 0.49$ & $0.83 \pm 0.26$ & $12.92 \pm 2.02$ & $1.12 \pm 0.27$ & Sc-per \\
\hline $\begin{array}{l}\text { G. spurium subsp. } \\
\text { spurium }\end{array}$ & $15.27 \pm 1.67$ & $15.93 \pm 2.19$ & O-s & $1.53 \pm 0.49$ & $0.73 \pm 0.25$ & $10.42 \pm 2.03$ & $1.14 \pm 0.34$ & Sc-per \\
\hline
\end{tabular}

P: Polar axis, E: Equatorial axis, P-s: Prolate-spheroidal, O-s: Oblate- spheroidal, S: Subprolate, clg: Colpus longitude (length), clt: Coplus latitude (width), Ex: Exine thikness, In: Intine thikness, Or: Ornamentation, Scper: Scabrate-perforate

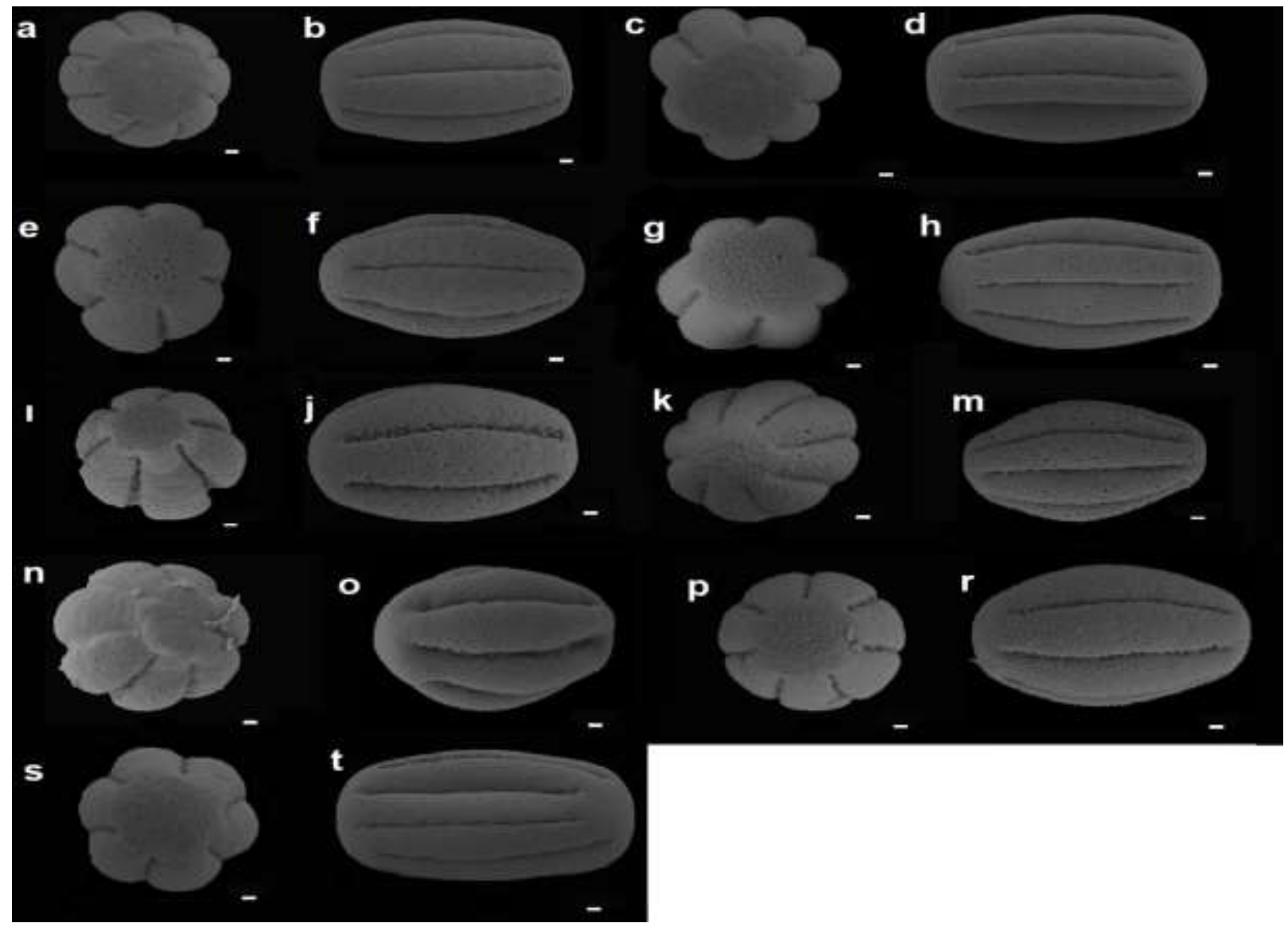

Figure 1. SEM micrograph of Asperula and Galium; Polar and Equatorial view: a-b: Asperula orientalis. c-d: A. arvensis, e-f: A. xylorrihza, g-h: Galium consanguineum, $\mathbf{- j}$ : G. mite, k-m: G. galiopsis, n-o: G. humufisum, p-r: G. incanum, s-t G. spurium. (Scale bar: $1 \mu \mathbf{m})$ 


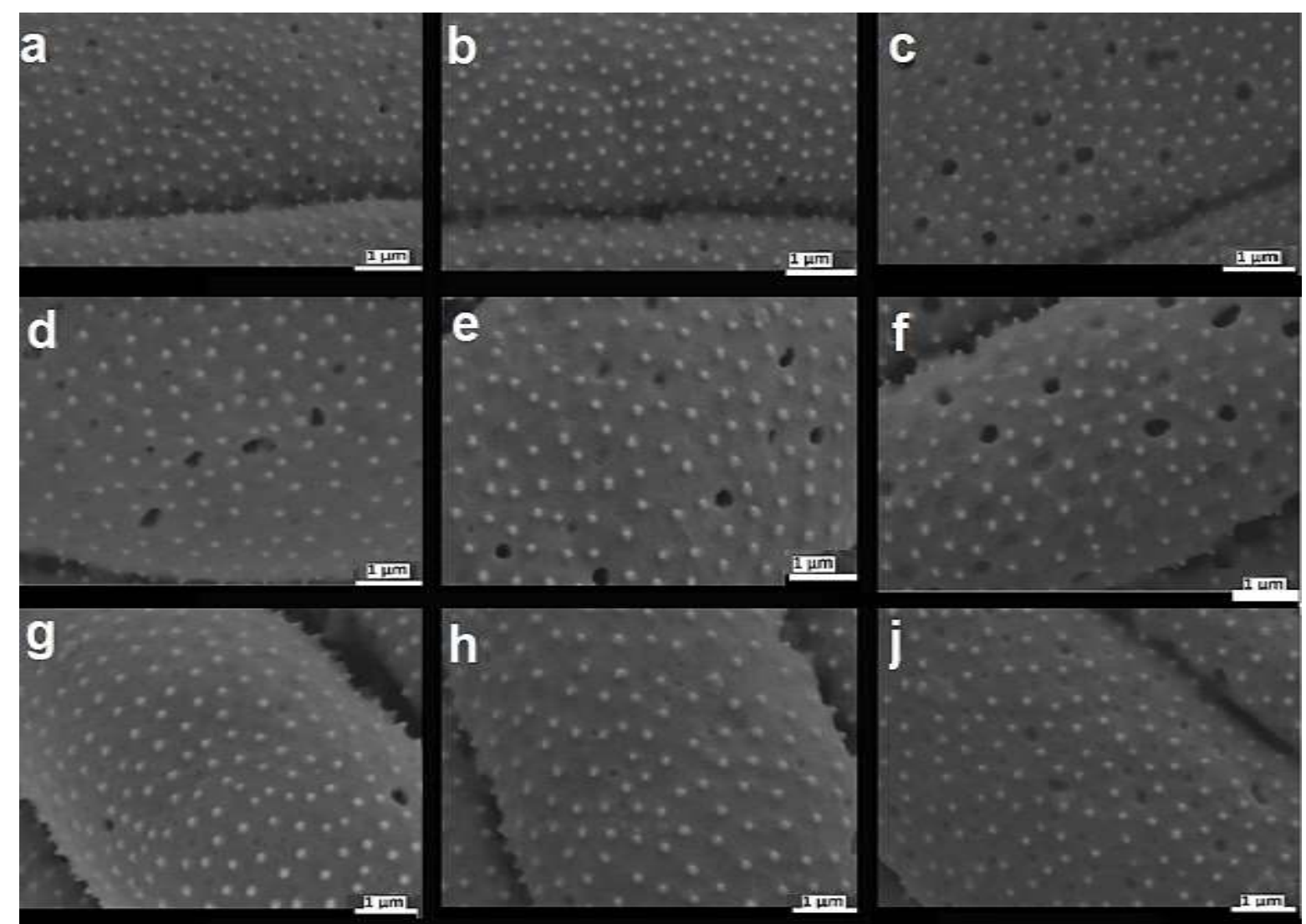

Figure 2. SEM micrograph of Asperula and Galium; Ornamentation a: Asperula orientalis.b: A. arvensis, c:

A. xylorrihza, d: Galium consanguineum, e: G. mite, f: G. galiopsis, g: G. humufisum, h: G. incanum, j: G. Spurium
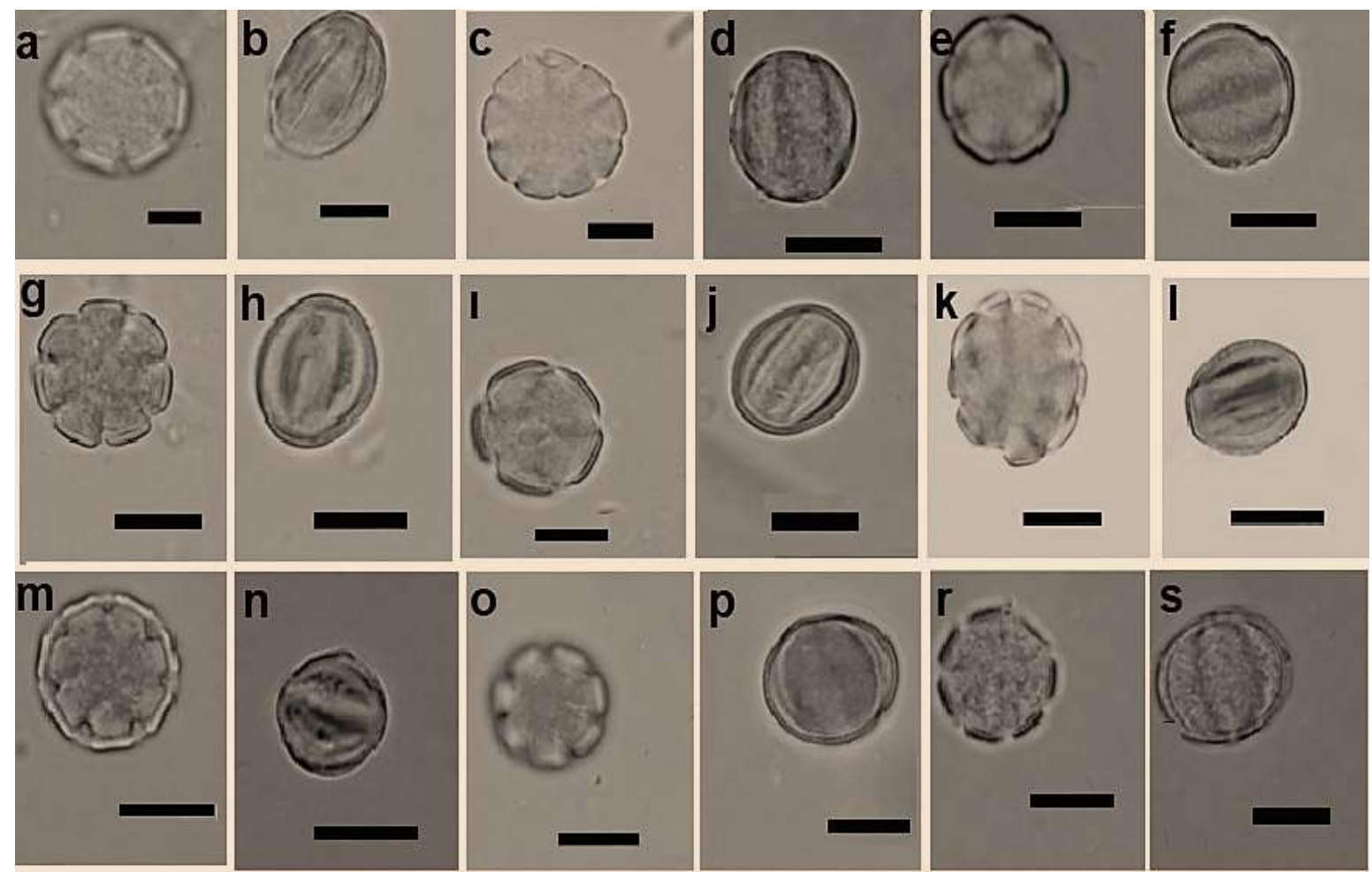

Figure 3. LM micrograph of the pollen of Asperula and Galium. Polar view and Equatorial view: a-b: Asperula orientalis. c-d: A. arvensis, e-f: A. xylorrihza, g-h: Galium consanguineum, $\mathbf{1 - j}:$ G. mite, k-l: G. galiopsis, m-n: G. humufisum, o-p: G. incanum, r-s G. spurium. (Scale bar: $10 \mu \mathbf{m}$ ) 


\section{Conclusions}

The pollen morphology of 9 taxa of Asperula L.and Galium L. genera in Rubiaceae family, using the plant samples, collected in the field studies in Elazığ and Bitlis provinces, was examined using light microscope and SEM in detail (Table 1; Figs 1-2-3).

As a result of the studies conducted on this family, the pollen was determined to be isopolar, pollen shapes with radial symmetry, suboblate, oblate-spheroidal, subprolate, and prolate-spheroidal. More common ones are subprolate and prolate-spheroidal, apertures of pollen range between colpate and 3-11 colpate and 6-7 colpate is found more frequently. Ornamentation type is scabrate, microechinate, rugulate and reticulate [7, 23-25]. In the previous studies conducted on Asperula species, the number of colpi was given to be 6-7 [26]. In the present study, the colpus number of the pollen of Asperula and Galium genera included in Rubiaceae family varied between 5 and 9 and also the shape of the pollen was determined to be prolate-spheroidal, oblate-spheroidal and subprolate (Table 1). At this point, the present study is compatible with the studies by Utzschneider [23]; Erdtman, [7]; Perveen and Qaiser [27]; Abdel Khalik et al., [18]; Minareci et al., [26]. In the study conducted by Huymans et al., [13] using acetolysis method, they stated that the pollen characteristics of 6 genera (Asperula, Galium, Crucianella, Cruciata, Rubia and Sherardia) of the tribe Rubieae included in Rubiaceae family were unique since these pollens have apertures with several colpate, perforate-microechinate ornamentation, small size, no endoapertures, a thick exine layer under ectocolpi and no orbiculi. They adapted the idea that these genera had similar pollen characteristics, there was no evolutionary change among the genera, and the main characteristics in the pollen structure were preserved. As a result of the study conducted with light microscope, it was determined that Asperula species had oblate-spheroidal and prolate-spheroidal pollen shapes and their ornamentation was reticulate, the exine layer thickness of the pollens was in the range of 1.44-2.25 $\mu \mathrm{m}$, intine layer of the pollen was in the range of $0.48-1.08$ $\mu \mathrm{m}$, polar axis length was 15.85-23.20 $\mu \mathrm{m}$, equatorial axis length was 16.14-22.88 $\mu \mathrm{m}$, colpus length was 11.04-17.59 $\mu \mathrm{m}$, and colpus width was 0.78-1.87 $\mu \mathrm{m}$ (Table 1). Minareci and Yildiz [27] conducted studies on the pollen morphology of five species included in Asperula. They found that pollen shapes was spheroidal, polar axis was 15.5-20.1 $\mu \mathrm{m}$, equatorial axis was 15.8-20.1 $\mu \mathrm{m}$, ornamentation of pollen was perforate-microechinate, number of colpi was $6-8$, colpus height was 10.4-14.6 $\mu \mathrm{m}$, and colpus width was $0.09-0.39$. They measured the perforae number of the pollen of the species examined as 12 36 in $5 \mu \mathrm{m}^{2}$.

Asperula is a stenopalynous genus, characterized by having monads and isosymmetric, very small, 5-8 zonocolpate and oblate-spheroidal, prolate- spheroidal. Exine ornamentation is scabrateperforate and the aperture membrane is scabrate. In the studies performed on SEM microphotos, we determined that the scabrae number of Asperula genus in $1 \mu \mathrm{m}^{2}$ was within the range of 9-25, perforae number was within the range of 1-5 and the length of scabrae was within the range of 0.11-0.14 $\mu \mathrm{m}$, and the width of scabrae was within the range of 0.14-0.21 $\mu \mathrm{m}$ (Figure $2 \mathrm{a}-\mathrm{c}$ ).

In the previous pollen studies conducted on Asperula species in Turkey, there are some differences such as the maximum pollen length of $19 \mu \mathrm{m}$ and mesocolpium of 6.4-6.6 $\mu \mathrm{m}$ [26]. In the present study, the pollen length of Asperula species was within the range of 20.87-25.66 $\mu \mathrm{m}$, mesocolpium was within the range of 22.22-24.60 $\mu \mathrm{m}$, and apocolpium was within the range of 2.51$2.90 \mu \mathrm{m}$ (Tabel 1).

Galium L. is a stenopalynous genus, characterized by having monads and isosymmetric, very small, 6-9 zonocolpate, oblate-spheroidal and prolate-spheroidal. Exine ornamentation is scabrateperforate and the aperture membran is scabrate (Table 1). It was determined in the present study that the number of scabrae in $1 \mu \mathrm{m}^{2}$ was within the range of 7-16, the number of perforae in $1 \mu \mathrm{m}^{2}$ was within the range of 1-9 and the length of scabrae was within the range of $0.10-0.19 \mu \mathrm{m}$, and the width of scabrae was within the range of 0.10-0.17 $\mu \mathrm{m}$ (figure $2 \mathrm{~d}-\mathrm{j}$ ). In the study conducted in Egypt, the pollen of 12 taxa of Galium L. genus were examined using light microscope (LM) and electron microscope (SEM). Colpus number was in the range of 5-10 and pollen shapes varied from prolate-spheroidal to oblatespheroidal. As also seen in G. aparine L., G. canum Req. ex DC., the most common shape of Galium L. genus was spheroidal. The remaining ones were spheroidal or suboblate. These results are compatible with the results of Huysmans et al., [13] on pollen shape. Pollen size range of many species was considered to be in conformity with each other but G. aparine L. may be distinguished with relatively bigger pollens compared to the other species. It was stated that the colpus number of pollen was within 
the range of 5-10. The pollen shapes were prolate-spheroidal, oblate-spheroidal, suboblate; the polar axis of pollens were within the range of $13.10-20.62 \mu \mathrm{m}$ and the equatorial axis of pollens were within the range of 13.19-20.55 $\mu \mathrm{m}$. This study conducted in Egypt proved the value of the pollen morphological characteristics of some species of Galium genus in systematic applications using light and electron microscope [18]. Abdel Khalik et al., [18] stated in their study on the species of Galium genus that the ornamentation of pollens was perforate-microechinate, their colpus number was within the range of 5-9, pollen shapes were spheroidal, prolate-spheroidal, oblate-spheroidal, sub-oblate, the length of polar axis was within the range of 13.1-20.62 $\mu \mathrm{m}$, length of equatorial axis was within the range of 13.19-21.51 $\mu \mathrm{m}$, and pollen were radial symmetric and isopolar. As a result of the examinations, they determined that the pollen of G. murale L., G. parisiense Pall. species was relatively larger, had less microspins and they were distinguished from the other species in terms of the density of scabrae. They revealed that the pollens of G. aparine species had 7-9 colpi, the pollens of G. spurium had 6-8 colpi, the pollens of G. ceratopodium species had 6-8 colpi, and the pollens of G. tricornutum Dandy species had 8-9 colpi.

Huymans et al., [13] stated that the pollens of G. parisiense species had 8 colpi but the pollens of G. murale and G. setaceum Lam. species had 6-7 colpi. It was determined that the pollen shapes of the species of Galium genus were oblate-spheroidal, subprolate, and prolate-spheroidal and their ornamentation was perforate-scabrate, their colpi number were 6-8 and rarely 9. Polar axis length of the pollens was 20.96-42.37 $\mu \mathrm{m}$ and length of equatorial axis was 19.72-30.26 $\mu \mathrm{m}$. While the perforate number of the pollen in $1 \mu \mathrm{m}^{2}$ was between 1-5, G. spurium species had perforates between 4-9 in $1 \mu \mathrm{m}^{2}$ unlike the others (Table 1, Figs. 1-2-3). Robbrecht [24] considered the shape, number, and ornamentation of apertures in determining the morphological differences of pollens and determined that the pollen of taxa in the tribe Pavetteae of Rubiaceae family was 3-zonocolporate, their polar axis were $15-42 \mu \mathrm{m}$, their equatorial axis were 16-42 $\mu \mathrm{m}$, they varied from oblate-spheroidal to prolate-spheroidal, and rarely as sub oblate and sub prolate in equatorial appearance and ectocolpus may be distinguished prominently with its width of $1-4.5 \mu \mathrm{m}$ in equator. In the present study, the polar axis length of the pollens of A. xylorrhiza species was $20.87 \mu \mathrm{m}$ and the polar axis length of the pollens of G. humifusum species was $42.37 \mu \mathrm{m}$. The polar axis length of the other species studied was within the range of 20.87$42.37 \mu \mathrm{m}$. The equatorial axis length of the pollen grains of $G$. incanum species was $19.72 \mu \mathrm{m}$ and the equatorial axis length of the pollen grains of $G$. humifusum species was $30.26 \mu \mathrm{m}$. The equatorial axis length of the other species studied was within the range of 19.72-30.26 $\mu \mathrm{m}$ (Table 1).

We obtained a correlation between our results and the classification of Asperula and Galium taxa, that is, pollen features, especially pollen size, the number of scabrae and perforae counted per $1 \mu \mathrm{m}^{2}$ proved to be the most useful characters for the systematics of these taxa

\section{Authors' Contributions}

Birol BAŞER as corresponding author contributed 60\% to this study, Serap AKDENIZ contributed 20\%, Murat KURŞAT contributed $20 \%$.

\section{Statement of Conflicts of Interest}

There is no conflict of interest betwwen the authors.

\section{Statement of Research and Publication Ethics}

The author declares that this study complies with Research and Publication Ethics.

\section{References}

[1] Ruhsam M., Govaerts R.H.A., Davis A.P. 2008. Nomenclatural changes in preparation for a World Rubiaceae checklist. Botanical Journal of the Linnean Society, 157 (1): 115-124.

[2] Seçmen Ö., Gemci Y., Leblebici E., Görk G., Bekat L. 1995. Tohumlu Bitkiler Sistematiği. Ege Üniv. Fen Fak. Kitaplar Serisi, No: 116, İzmir. 
[3] Davis P.H. 1982. Flora of Turkey and the East Aegean Islands. Volume 7. Edinburgh: Edinburgh University Press, 722-767.

[4] Davis P.H., Mill R.R., Tan K. 1988. Flora of Turkey and the East Aegean Islands. Volume 10, suppl. 1, Edinburgh Univ. Press. Edinburgh.

[5] Özhatay N. 2000. Flora of Turkey and the east Aegean Islands. Volume 11, suppl. 2, Edinburgh Univ. Press. Edinburgh.

[6] Güner A., Aslan S., Ekim T., Vural M., Babaç M.T. 2012. Türkiye Bitkileri Listesi (Damarlı Bitkiler). Flora Araştırmaları Derneği ve Nezahat Gökyiğit Botanik Bahçesi Yayını, İstanbul.

[7] Erdtman G. 1952. Pollen morphology and plant taxonomy angiosperms. Chronica Botanica Co., Waltham, Massachusettes.

[8] Erdtman G. 1971. Pollen morphology and plant taxonomy: Angiosperms. Hafner, New York.

[9] Bremekamp C.E.B. 1952. The African species of Oldenlandia L. sensu Hiern et K. Schuman. Verh. Kon. Ned. Akad. Wetensch., Afd. Natuurk., Tweed Sect., 48: 1-297.

[10] Lobreau-Callen D. 1978. L'aperture composê des Rubiaceae. Extr. Ann. Mines Belg., 2: 167-173.

[11] Van Campo M. 1978. La face interne de l'exine. Rev. Palaeobot. Palynol., 26: 301-311.

[12] Muller J. 1981. Fossil Pollen records of Extant angiosperms. Bot. Rev. (Lancaster), 47: 1-142.

[13] Huysmans S., Dessein S., Smets E., Robbrecht E., 2003. Pollen morphology of NW European representatives confirms monophyly of Rubieae (Rubiaceae). Review of Palaeobotany and Palynology, 127: 219-240.

[14] Dessein S., Huysmans S., Robbrecht E., Smets E. 2002. Pollen of African Spermacoce Species (Rubiaceae) morphology and evolutionary aspects. Grana, 41: 69-89.

[15] Dessein S., Ochoterena H., De Block H., Lens F., Robbrecht E., Schols P., Smets E., Vinckier S., Huysmans S. 2005. Palynological characters and their phylogenatic signal in Rubiaceae. Bot. Rev., 71 (3): 354-414.

[16] Verellen J., Dessein S., Razafimandimbison S.G., Smets E., Huysmans S. 2007. Pollen morphologyof the tribes Naucleeae and Hymenodictyeae (Rubiaceae-Cinchonoideae) and its phylogenetic significance. Botanical Journal of the Linnean Society, 153: 329-341.

[17] Perveen A., Qaiser M. 2007. Pollen flora of Pakistan-Liv Rubiaceae. Pakistan Journal of Botany, 39: 999-1015.

[18] Abdel Khalik K., Abd El-Ghani M.M., Elkordy A. 2007. A palynological study of Galium L. (Rubiaceae) in Egypt and its systematic implication. Article in Feddes Repertorium·December, 317: 311-326.

[19] Wodehouse R.P. 1935. Pollen Grains. M.C. Graw, Hill N.Y.

[20] Hesse M., Halbritter H., Zetter R., Weber M., Buchner R., Frosch-Radivo A., Ulrich S. 2009. Pollen Terminology, An illustrated handbook. pp. 15-23. Springer-Verlag/Wien, Austria.

[21] Punt W., Blackmore S., Nilsson S., Le Thomas A. 1994. Glossary of Pollen and Spore Terminology. LPP Foundation, Utrecht, 1-246.

[22] Punt W., Hoen P.P., Blackmore S., Nilsson S., Le Thomas A. 2007. Glossary of Pollen and SporeTerminology. Rev Palaeobot Palynol. 143: 1-81.

[23] Utzschneider R. 1947. Der Fruchtknotenbau der Rubiaceeen mit besonderer Berücksichtigung der Cinchonoideen. Ph.D. Dissertation, University of Munich.

[24] Robbrecht E. 1982. Pollen morphology of the tribes Anthospermeae and Paederieae (Rubiaceae) in relation to taxonomy. Bull. Jard. Bot. Nat. Bel., 52: 349-366.

[25] Qauser M., Perveen A. 1997. A Palynological survey of flora of Pakistan, In M. Ozturk, O. Secmen and G. Gork (Eds.), Proceedings of Int. Symp. On Plant life of South West Asia and Central Asia.

[26] Minareci E., Yıldız K., Çırpıcı A. 2010. Comparative morphological and palynological study on poorly known Asperula serotina and its closest relative A. purpurea subsp. apiculata. Scientific Research and Essays, 5: 2472-2479.

[27] Minareci E., Yıldız K. 2010. Asperula pseudochlorantha var. antalyensis comb. et stat. nov. (Rubiaceae). Ann. Bot. Fennici, 47: 121-128. 